D. V. Babets ${ }^{1}$, orcid.org/0000-0002-5486-9268, O.S. Kovrov ${ }^{1}$, orcid.org/0000-0003-3364-119X, S. K. Moldabayev ${ }^{2}$, orcid.org/0000-0001-8913-9014, R. M. Tereschuk ${ }^{1}$, orcid.org/0000-0003-4509-2511, D. O. Sosna ${ }^{1}$, orcid.org/0000-0002-0521-8661

\title{
IMPACT OF WATER SATURATION EFFECT ON SEDIMENTARY ROCKS STRENGTH PROPERTIES
}

Purpose. To identify some regularities of reduction in strength of loamy soils and weak sedimentary rocks that are typical for Western Donbas by water saturation condition for assessment of their stability in geotechnologies and forecasting geohazards.

Methodology. The paper presents two techniques of experimental testing for sedimentary rocks that allow determining their strength properties under the condition of water saturation. Rock samples of sandstones, mudstones, and siltstones after artificial saturation with mine water were tested on a KL 200/CE hydraulic press to determine the uniaxial compressive strength value. The method for determining the physical-mechanical properties for soft loamy rock samples under different water saturation using PS-10 single-plane shearing tester was used.

Findings. Based on the results of compression tests, strength characteristics are obtained for samples of sandstones, mudstones, and siltstones, in particular, the values of uniaxial compression strength at various degrees of water saturation. Statistical processing of the obtained experimental data was applied. A relative variation in the values of compressive strength was established for various rates of water saturation; regression dependences of the strength loss for sedimentary rocks depending on the water content in rock samples were plotted. The values of cohesion $\mathrm{C}$ and the angle of internal friction $\varphi$ for soft loamy rocks are obtained depending on water saturation.

Originality. It was established that the relative variation of the uniaxial compressive strength increases with increasing water content in sedimentary rock samples. The most intense decrease in the strength of sandstones, mudstones, and siltstones samples occurs with increasing water content from 1 to $2 \%$. In a water-saturated state, the strength of some sedimentary rocks under conditions of Western Donbas decreases by 1.5-2.5 times. The critical values of the strength properties of soft loamy rocks are established depending on water saturation, at which deformation processes are initiated: for light yellow loess loams $-C=17 \mathrm{kPa}$ and $\varphi=14^{\circ}$; for yellow-brown dense loams $-C=29 \mathrm{kPa}$ and $\varphi=17^{\circ}$.

Practical value. Correction coefficients for water saturation were obtained to determine the estimated physical and mechanical characteristics of sedimentary rocks of Western Donbas, which allows predicting geomechanical processes in the rock mass and determining the parameters of geomechanical systems. The obtained values of cohesion and angle of internal friction for loamy rocks depending on water saturation allow predicting stable parameters of open-pit slopes and dumps.

Keywords: Western Donbas, sedimentary rocks, water saturation, uniaxial compression strength, angle of internal friction, rock cohesion

Introduction. Water saturation of rocks is a characteristic that is determined by external environmental conditions, as well as the size and nature of the rock porosity and its structural and textural features.

Besides, to eliminate the effects of moisture impact, the determination of the physical and mechanical properties of rocks is usually performed with air-dried samples. Therefore, water saturation does not appear in the domestic classifications of the basic physical properties of rocks. In this regard, the data focusing on uniaxial compressive strength under the condition of natural water saturation in particular in Western Donbas, are of special importance.

The effect of water saturation is different for various types of rocks. For example, rocks with low porosity have, accordingly, low moisture content. Since it does not exceed percentages, it can be neglected for practical calculations. Weak rocks can already have high water saturation, up to $15-20 \%$, but the widest range of water saturation fluctuations is characteristic for dispersed rocks. For such rocks, the effect of moistening on strength properties becomes significant, and therefore it must be taken into consideration.

Establishing the physical and mechanical properties of rocks, and studying their changes when moistened directly in the rock mass is almost impossible in situ, so the studies are usually performed in the laboratory when moistening samples with mine water.

(C) Babets D.V., Kovrov O.S., Moldabayev S.K., Tereschuk R. M., Sosna D. O., 2020
For soft sedimentary rocks, in particular loess soils, loams and clays, the water saturation of the massif significantly affects their physical and mechanical properties, which is important in particular for technologies of surface mining, civil and industrial construction, and assessment of geodynamic phenomena of lithosphere surface layers. The most applied aspect in these areas is the forecast of stability and landslide hazard of natural and man-made slopes by water saturation of soils and loams due to the influence of groundwaters or atmospheric precipitation.

Loess soils are fine-grained and wind-eroded sediments which have homogeneous and highly porous structure. They are mainly composed of fine sand and clay, with grain sizes ranging from 0.005 to $0.05 \mathrm{~mm}$. Due to high porosity and welldeveloped vertical joints the water can easily flow inside the soft soils and clays both vertically and horizontally that drastically reflects on their physical properties [1].

Soft cohesive rocks are characterized by plastic deformations, relatively low strength properties, and permeability, and high moisture content. The presence of cracks and stratification layers in such rocks is one of the favorable factors for intensification of swelling processes in clay rocks resulted in getting plastic state, accompanied by the occurrence of contact landslides.

Taking the above mentioned into consideration, the assessment of the impact of water saturation of sedimentary rocks on their physical and mechanical characteristics is a sphere of important and applied interest.

Literature review. Many scientific papers are devoted to the study on water saturation of rocks and the influence of moisture effect on the rock mass strength properties due to the ap- 
plied significance of this problem for mining technologies, industrial and civil construction engineering.

In general, the strength parameters of rocks often show a tendency to decrease with increasing water saturation. Accurate estimation of rock strength parameters is of great importance in many engineering practices, especially for assessment of underground structures stability in soft rocks. Determining the strength of a rock mass is one of the main problems in geomechanical studies. The method for determining the strength of rocks depending on the structure and texture of the rock mass based on the statistical strength theory, presented in [2], can be significantly improved by taking into account the influence of moisture saturation.

Due to the considerable variations of texture, lithology, and other factors the extent of water saturation effect is highly varied among different rock types, spanning from nearly negligible in quartzite to $90 \%$ of uniaxial compressive strength reduction in shale [3]. The term "other factors" includes, for example, temperature, thus in [4] research of water saturation effect has been conducted in cold climates where the temperature of the soil and rocks near the earth's surface often falls below the water freezing point. The properties of rocks in the air-dry state, moisture-saturated state, and partially saturated were studied and the presence of water in the rock has resulted in a marked increase in rock strength. Therefore, this remarkable result is not applicable to draw any conclusions about the influence of moisture on the strength and deformation properties of rocks under conditions of Ukrainian coal mines.

In [5] the elastic properties of rocks of diamond deposits in Yakutia (Russia) were investigated. The rock samples of limestone and siltstone in the air-dry and wet state were tested for uniaxial compression. Experimental regularities of changes in the elastic properties of rock samples with a change in their state, characterized by the amount of excess (compared to the air-dry state) moisture in the sample were established. However, such an important characteristic as the uniaxial compressive strength has been overlooked.

The effect of water saturation on the mechanical properties of low-permeability rocks was studied in [6]. A series of uniaxial compression strength tests were conducted on siltstone samples under different water saturation levels, and the water degradation effects on the mechanical properties were observed. A negative exponential relationship for siltstone was established between the uniaxial compressive strength and the water saturation level. In [7] to investigate the water-weakening effects on mechanical behavior and reveal the weakening mechanisms for different types of hard rocks of China mines, a series of uniaxial compression tests were carried out on sandstone, granite, and marble samples in dried and water-saturated states. It was specified that the weakening degree varies with rock type: the mechanical properties of the sandstone are the most susceptible to water, followed by the granite and the marble.

These results were taken into consideration for verification of findings in the given paper.

Physical and mechanical properties of loess soils also vary depending on the origin and moisture saturation. Disasters of geological origin and landslides are caused by structural properties of loamy rocks [8].

In [9], the dependencies of specific cohesion and internal friction angle on external loads on the soil were established, which allows improving the method for calculating the strength properties of the soil from the average pressure on the soil under the foundation base. However, the study does not take into consideration the potential effect of moisture saturation of soils or soft rocks on their strength properties.

The paper [10] deals with the analysis of water-saturated rocks strength properties, which allows determining the critical load on the surface of slopes, trenches, and ditches, as well as other excavations in soils and rocks. But the authors do not show how the water saturation of soils affects the slope stability safety factor.
In loess massifs, the soils are partially in a state of plastic flow due to water oversaturation, which can lead to the failure of buildings and structures foundations [11]. The phenomenon of water oversaturation in soils due groundwater impact or atmospheric precipitation is associated with effects of soil microstructure and soil suction that causes the decrease of shear strength properties and stability of loess soils [12]

Wetting of the upper layers of sedimentary rocks, in particular loams and sands, significantly reduces the efficiency of open-pit mining technology [13]. In such mining and geological conditions, the most environmentally efficient technological scheme of open pit development is a scheme using a hydromechanical method of mineral development.

A brief analysis of recent publications on the topic of rocks water saturation concerning their physical and mechanical characteristics shows the importance of this problem in both scientific and applied aspects.

Unsolved aspects of the problem. The analysis of recent research shows that a lot of scientific publications both in our country and abroad are devoted to the study on the influence of moisture on the strength and deformation properties of coal and rocks. However, most studies have been focused on the problems of hydrocarbon development in deep mines or regarding mine rocks typical to the mines of Central Donbas (Ukraine), Kuzbass (Russia), and China and therefore the results cannot be fully applied for solving the problems of stability of coal mine excavations in Western Donbas. Quantitative estimation of the influence of moisture saturation on the decrease in strength of weak rocks is an important component for developing the stochastic model of strength. Such a model is the basis of mathematical modeling of stress-strain state of rock mass using the finite element analysis to ensure the stability of mine excavations under specific mining and geological conditions [14].

For soft rocks and loams, the determination of cohesion and internal friction angle under conditions of moisture saturation is the initial stage for engineering assessment of the stressstrain state of the rock mass for the forecasting dangerous geodynamic phenomena. Despite a large number of studies on the influence of hydrogeological factors on the rock mass, laboratory determination of the strength of loamy rocks in a wide range of water saturation remains an important research task.

Purpose. Taking into consideration the analysis of recent studies and publications, the paper objective is an identification of regularities of reduction in strength of loamy soils and weak sedimentary rocks that are typical for Western Donbas by water saturation condition for assessment of their stability in geotechnologies and forecasting geohazards.

The tasks of the paper are as follows:

1. To conduct a series of compression tests with the samples of sandstones, siltstones, and mudstones under conditions of variable water saturation and determine the statistical characteristics of uniaxial compressive strength values.

2. To establish regularities of uniaxial compressive strength change depending on the degree of water saturation.

3 . To perform laboratory tests with the samples of soft loamy rocks under conditions of variable water saturation and determine cohesion and internal friction angle values.

4. To build prognostic models of changes in soil strength characteristics depending on the degree of moisture saturation.

Methods for determining the effect of water saturation on the uniaxial compression strength of sedimentary rock. The specimens of sandstones, siltstones, and mudstones from Samaraska coal mine of DTEK Pavlohradvuhillia were tested. Two types of specimens were made using a TCM 350 stone cutting machine by SOLGA DIAMANT (Spain). The prismatic specimens (with a square cross-section) were made of fragments of rocks and cylindrical samples (with a circular cross-section) were obtained from cores.

The water content rate of rock samples was determined by comparing the weight of the samples in a water-saturated state and after drying. 
Samples preparation for testing in the water-saturated state was performed as follows:

1. The samples were weighed and then submerged into a container with mine water.

2. The saturation process lasted for $10-50$ minutes to obtain a different water content rate.

3. To determine the ability of the samples to "soak" two samples of each type of rock were immersed into water for 24 hours.

To determine the water content rate of a specimen group that was immersed in water for the same time, one sample was selected. This sample was weighed in a closed container. Then the container was opened and placed in a heated muffle furnace. The sample was dried at temperature $t=100^{\circ} \mathrm{C}$. After drying the sample was cooled to room temperature and weighed again.

The water content rate of the rock sample $(W, \%)$ was defined as the ratio of the weight of water that was removed from the rock by drying to the weight of dry rock according to the formula

$$
W=\frac{m_{W}-m_{0}}{m_{0}-m_{k}} \cdot 100 \%,
$$

where $m_{W}$ is the weight of moisture rock with container and lid; $m_{0}$ is the mass of the dried rock with the container and the lid; $m_{k}$ is the weight of the empty container with the lid.

After determining the water content rate, samples of the same rate of water saturation were tested using the hydraulic machine KL 200/CE by TECNOTEST (Italy). To conduct the uniaxial compression strength test, the samples were loaded uniformly to failure at a rate of $2 \mathrm{MPa} / \mathrm{s}$. The test results were recorded in the log of the experiment and the main statistical characteristics were obtained for each group of samples.

Methods for determining the effect of water saturation on the strength properties of soft loams. The values of cohesion $C$ and the angle of internal friction $\varphi$ are parameters of the dependence of soil resistance to a shearing force, which are necessary for engineering calculations of strength and stability of soil and soft overburden rocks, as well as their pressure on foundations and structures.

The resistance of soft rocks and soils to shearing force is expressed by the Mohr-Coulomb equation

$$
\tau=\sigma \operatorname{tg} \varphi+C,
$$

where $\tau$ is limit shearing stress; $\sigma$ is normal stress; $\varphi$ is the angle of internal friction; $C$ is cohesion.

To determine the strength properties of loams, the portable tester PS-10 with single-plane shear was used. This tester is designed for field and stationary tests for clay and organic-mineral soils to determine the angle of internal friction and cohesion values. The method of laboratory tests is regulated by Ukrainian standard DSTU B B.2.1-4-96 "Rocks. Methods of laboratory determination of strength and deformation characteristics".

Monolithic samples of rocks with intact structure and natural water saturation were taken at different sites of the open-pit of Vilnohirsk Mining and Metallurgical Plant (Vilnohirsk, Ukraine) to perform a series of shearing tests. Samples of the upper overburden, represented by light-yellow loess loams and yellow-brown dense loams, were taken at the sites where the soft sedimentary rocks were outcropped due to stripping operations or undergone landslide processes. In order to preserve the natural moisture, plastic bags were used for packing rock samples

Tests of loam samples to determine their physical and mechanical characteristics were performed in the laboratory on a single-plane shear tester PS-10 at normal loads of $0.1,0.2$, and $0.3 \mathrm{MPa}$. The following characteristics were determined: shear strength $\tau$, internal friction angle $\varphi$ and specific cohesion $C$. To determine the shear strength, the samples taken by compression sleeves in the form of a cylinder with a diameter of $56 \mathrm{~mm}$ and a height of $20 \mathrm{~mm}$, were used. The tests were performed without water saturation based on the natural moisture of the samples, as well as with water saturation and gradual drying and further determination of strength parameters.
The tangential and normal stresses $\tau$ and $\sigma$ were determined from the values of the tangential and normal loads measured during the tests. The study on the dependences of the strength properties of loams on the degree of their water saturation was carried out using a moisture meter KERN MLB [15].

Results of laboratory tests for hard sedimentary rocks. According to experimental studies the specimens of sandstones do not get soaked in water regardless of the moisturizing time. Mudstones and siltstones at high moisture for 5-10 hours get soaked and crumble into small pieces (completely lose the strength). This result can be used in the study on the geomechanical situation that arises when closing coal mines by flooding.

In the framework of these studies, it is important to establish the dependence of natural moisture on rock strength. When analyzing the laboratory test results, it is clear that sandstones lose about 5-7 \% of strength with increasing water content rate from 1 to $5 \%$, siltstones lose about $15-30 \%$ of strength, and mudstones $-40-60 \%$. The results of the statistical processing of the experimental data are given in $\mathrm{Ta}$ bles $1-3$ and visualized on the diagram (Fig. 1).

The analysis of the diagram (Fig. 1) shows that all types of sedimentary rocks, which were studied, decrease their strength during water saturation. The most intense decrease in strength is observed when the water content increases from $W=1$ to $2 \%$.

As a result of the statistical analysis of experimental data, the regression dependences of water content rate on strength of sedimentary rock of Western Donbas coal mines were established. These dependencies are represented in Fig. 2.

Therefore, the loss of strength of the rock sample regarding water saturation can be calculated by the following empirical formulas. For sandstones

$$
\sigma_{W} / \sigma_{\max }=-0.043 \ln (W)+0.9655=K_{W 1},
$$

for siltstones

Table 1

Sandstones sample statistics for uniaxial compressive strength depending on the water content

\begin{tabular}{|l|c|c|c|c|c|}
\hline \multicolumn{1}{|c|}{$W, 1 \%$} & $0-1 \%$ & $1-2 \%$ & $2-3 \%$ & $3-4 \%$ & $4-5 \%$ \\
\hline Mean value $\left(\sigma_{\mathrm{c}}\right), \mathrm{MPa}$ & 50.39 & 48.68 & 48.11 & 47.08 & 46.36 \\
\hline Variance & 60.29 & 62.11 & 78.03 & 84.00 & 92.81 \\
\hline Standard deviation & 7.76 & 7.88 & 8.83 & 9.16 & 9.63 \\
\hline Variation & 0.15 & 0.16 & 0.18 & 0.19 & 0.21 \\
\hline
\end{tabular}

Table 2

Siltstones sample statistics for uniaxial compressive strength depending on the water content

\begin{tabular}{|l|c|c|c|c|c|}
\hline \multicolumn{1}{|c|}{$W, \%$} & $0-1 \%$ & $1-2 \%$ & $2-3 \%$ & $3-4 \%$ & $4-5 \%$ \\
\hline Mean value $\left(\sigma_{\mathrm{c}}\right), \mathrm{MPa}$ & 25.22 & 20.61 & 18.90 & 17.53 & 16.47 \\
\hline Variance & 38.16 & 35.73 & 38.59 & 31.85 & 32.12 \\
\hline Standard deviation & 6.17 & 5.97 & 6.21 & 5.64 & 5.66 \\
\hline Variation & 0.24 & 0.29 & 0.33 & 0.32 & 0.35 \\
\hline
\end{tabular}

Table 3

Mudstones sample statistics for uniaxial compressive strength depending on the water content

\begin{tabular}{|l|c|c|c|c|c|}
\hline \multicolumn{1}{|c|}{$W, \%$} & $0-1 \%$ & $1-2 \%$ & $2-3 \%$ & $3-4 \%$ & $4-5 \%$ \\
\hline Mean value $\left(\sigma_{\mathrm{c}}\right), \mathrm{MPa}$ & 23.89 & 17.76 & 15.18 & 12.82 & 10.59 \\
\hline Variance & 19.51 & 20.60 & 18.13 & 17.12 & 14.67 \\
\hline Standard deviation & 4.42 & 4.53 & 4.25 & 4.13 & 3.83 \\
\hline Variation & 0.18 & 0.25 & 0.28 & 0.32 & 0.36 \\
\hline
\end{tabular}




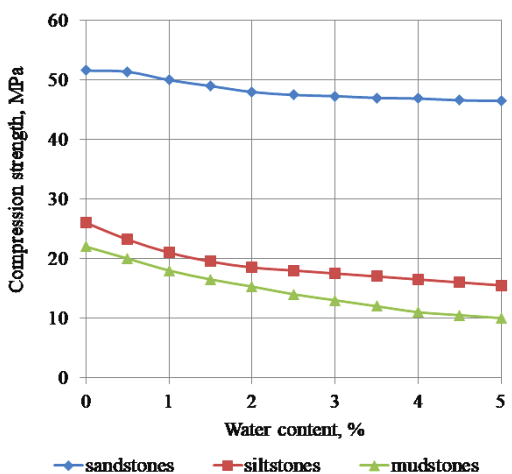

Fig. 1. Dependencies of uniaxial compressive strength for sandstones, siltstones, and mudstones on water saturation

$$
\sigma_{W} / \sigma_{\max }=-0.106 \ln (W)+0.7863=K_{W 2},
$$

for mudstones

$$
\sigma_{W} / \sigma_{\max }=0.973 \cdot e^{-0.16 W}=K_{W 3},
$$

where $\sigma_{W}$ is uniaxial compressive strength at water content rate $W$ $(\%) ; \sigma_{\max }$ is uniaxial compressive strength of the air-dried sample.

The numerical factors that allow adjusting properties of rock samples to the properties of rock mass under natural conditions "in situ" are very important in geomechanics. Based on the obtained regression dependences (3-5), such factors for sedimentary rocks of Western Donbas can be denoted as the water content coefficient $\left(K_{W i}\right)$, where $i=1$ for sandstones, $i=2$ for siltstones and $i=3$ for mudstones.

Results of laboratory tests for soft rocks. The values of cohesion and internal friction angles were obtained via the laboratory tests for soft rocks. Some physical characteristics of loamy rocks, defined by DSTU B V. 2.1-3-96 "Foundations of buildings and structures. Soils. Laboratory tests" are presented

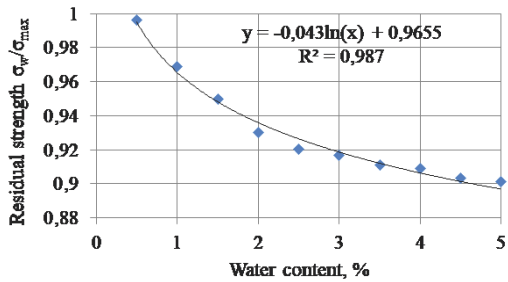

$a$
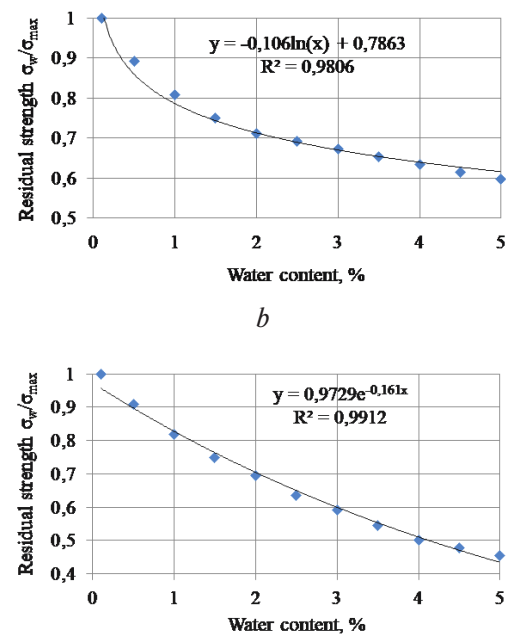

$c$

Fig. 2. The regression dependences of strength decrease for sedimentary rocks:

$a$-sandstones; $b$ - siltstones; $c$ - mudstones in Table 4. Porosity for light-yellow loess loams and yellowbrown dense loams is 41.0 and $39.6 \%$ respectively.

To prepare soil samples at given moisture saturation, the loamy rocks were first soaked up to full water saturation, then gradually dried in a muffle furnace at $t=100-105{ }^{\circ} \mathrm{C}$. The degree of water saturation in the samples was tested using a KERN MLB moisture meter [16]. It was established that in half an hour of drying the sample loses approximately 4-5\% of the initial water saturation, which allowed preparing the required number of samples of loams of given moisture for their testing in a shearing tester PS- 10 .

The prepared samples with different values of water saturation were subjected to shear tests according to the above-described technique, resulting in a relationship between the normal loads applied to the sample and its shear resistance. Fig. 3 presents the results of testing samples of loamy rocks under shearing loads with dependencies of cohesion and internal friction angle values on the water saturation of the samples.

For light-yellow loams, the strength properties by water saturation are reduced by the following dependences: for cohesion $y=0.028 x^{2}-2.419 x+53.682\left(R^{2}=0.995\right)$ and for internal friction angle $y=0.017 x^{2}-1.317 x+33.320\left(R^{2}=0.997\right)$. At experimentally set water saturation values $W=9.6-29.5 \%$ the values of cohesion and internal friction angle vary in the ranges $C=6.0-23.9 \mathrm{kPa}$ and $\varphi=9.2-22.4^{\circ}$.

For yellow-brown dense loams, the decrease in strength properties from water saturation is described by polynomials:

Table 4

\begin{tabular}{|c|c|c|c|c|}
\hline \multirow{2}{*}{$\begin{array}{c}\text { Soft } \\
\text { sedimentary } \\
\text { rocks }\end{array}$} & \multirow{2}{*}{$\begin{array}{c}\text { Unit } \\
\text { weight } \rho \text {, } \\
\mathrm{g} / \mathrm{cm}^{3}\end{array}$} & \multicolumn{3}{|c|}{$\begin{array}{l}\text { Averaged values of water saturation of } \\
\text { loams }\end{array}$} \\
\hline & & $\begin{array}{c}\text { natural } \\
W, \%\end{array}$ & $\begin{array}{c}\text { on the verge } \\
\text { of rolling } \\
W_{l}, \%\end{array}$ & $\begin{array}{c}\text { on the verge } \\
\text { of fluidity } \\
W_{f}, \%\end{array}$ \\
\hline $\begin{array}{l}\text { Light-yellow } \\
\text { loess loams }\end{array}$ & $1.55-1.62$ & 10.6 & 19.23 & 28.35 \\
\hline $\begin{array}{l}\text { Yellow-brown } \\
\text { dense loams }\end{array}$ & $1.60-1.75$ & 11.8 & 21.54 & 30.79 \\
\hline
\end{tabular}

Physical characteristics of soft rock samples
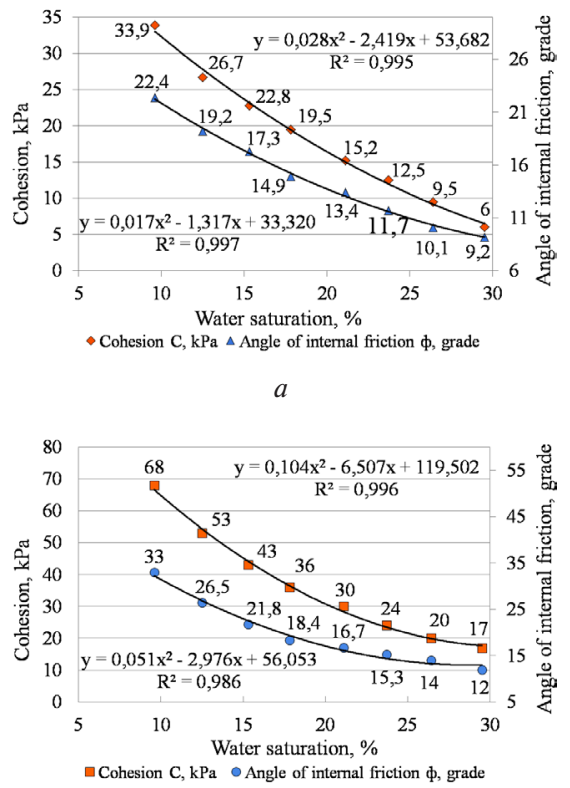

b

Fig. 3. Dependencies of cohesion and internal friction angle for light-yellow loess loams (a) and yellow-brown dense loams (b) on water saturation 
for cohesion $y=0.104 x^{2}-6.507 x+119.502\left(R^{2}=0.996\right)$ and for internal friction angle $y=0.051 x^{2}-2.976 x+56.053\left(R^{2}=\right.$ $=0.986)$. At a given range of water saturation $W=9.6-29.5 \%$ the values of cohesion and internal friction angle vary in the ranges $C=17.0-68.0 \mathrm{kPa}$ and $\varphi=12.0-33.0^{\circ}$.

The average values of soil moisture at the rolling limit correspond to the stage of transition of the soft loamy rock mass to the plastic state. At open-pit mining sites, such a change in soft rock properties causes a decrease in the geomechanical strength of the rock massif and the initiation of landslides in the slopes of the quarry. Thus, $W_{p}=19.23 \%$ for light-yellow loess loams and $W_{p}=21.54 \%$ for yellow-brown dense loams correspond to the critical values of cohesion and internal friction angle at the specified water saturation of rocks. Thus, the critical values of strength properties at which shear processes in the rock mass of soft sedimentary rocks are initiated are established: for light-yellow loams: $C=17 \mathrm{kPa}$ and $\varphi=14^{\circ}$; and for yellow-brown dense loams, $C=29 \mathrm{kPa}$ and $\varphi=17^{\circ}$.

The obtained dependencies can be used in finite element method software as initial data for geotechnical analysis of the stability of various structures and technical objects in the process of their construction and operation. In particular, reliable values of cohesion and internal friction angle for soft sedimentary rocks are important parameters for assessment of the stability of natural and man-made slopes to forecast their landslide hazard in changing geo-climatic conditions.

Conclusions. The water saturation ability of different genesis sedimentary rocks has a great practical value in engineering practice. Correct determining of the compression strength of hard sedimentary rocks allows developing adequate methods to control the stress-strain state of the rock mass during underground mining.

The study of the strength properties of sedimentary rocks (sandstones, siltstones, and mudstones) which are normal for Western Donbas coal mines under the effect of water saturation was conducted. The main results are as follows:

- moisturizing of sedimentary rocks leads to a decrease in their strength properties. In the water-saturated state, the strength of siltstones and mudstones in Western Donbas is reduced by $1.5-2.5$ times concerning air-dry state;

- the relative variation of the uniaxial compressive strength, that is the most important statistic characteristic for determining the structural factor [16], increases with increasing water content in sedimentary rock samples;

- the influence of water saturation must be taken into account when forecasting geomechanical processes and determining the parameters of mining. Thus, the adjusting factors between properties of rock sample and a rock mass "in situ" under natural conditions that are obtained in the given study are valuable for determining the values of the physical and mechanical properties of a rock mass.

The properties of such rocks as loams and clays largely depend on the parameters of cohesion and internal friction angle, whose values in changing geo-technological and hydrogeological conditions vary widely depending on the water saturation of the rock mass. These characteristics significantly affect the geomechanical stability of slopes of open-pits and dumps during surface mining.

Overwatering of loamy rocks and soils leads to deformations of open pit slopes with the emergence of local or largescale landslides, which negatively affect the technical and economic performance of open-pit mining operations. Critical values of water saturation and strength properties of loams, at which landslide processes start in the rock mass of soft sedimentary rocks have been established. Thus, for light-yellow loams, $C=17 \mathrm{kPa}$ and $\varphi=14^{\circ}$ at water saturation $W_{p}=19.23 \%$, and for yellow-brown dense loams $-C=$ $=29 \mathrm{kPa}$ and $\varphi=17^{\circ}, W_{p}=21.54 \%$ at water saturation $W_{p}=21.54 \%$, that corresponds to the state of landslide initiation.

\section{References.}

1. Li, P., \& Qian, H. (2018). Water in Loess. In: Encyclopedia of Sustainability Science and Technology. Springer. https://doi. org/10.1007/978-1-4939-2493-6_968-1.

2. Babets, D. (2018). Rock Mass Strength Estimation Using Structural Factor Based on Statistical Strength Theory. Solid State Phenomena, 277, 111-122. https://doi.org/10.4028/ www.scientific.net/SSP.277.111.

3. Wong, L. N. Y., Maruvanchery, V., \& Liu, G. (2016). Water effects on rock strength and stiffness degradation. Acta Geotech, 11, 713-737. https://doi.org/10.1007/s11440-015-0407-7. 4. Liu, B., Sun, Y., Wang, B., Han, Ya., Zhang, R., \& Wang, J. (2020). Effect of water content on mechanical and electrical characteristics of the water-rich sandstone during freezing. Environmental Earth Sciences, 79, 236. https://doi.org/10.1007/s12665020-08991-8.

5. Suknev, S. V. (2016). Determination of the static modulus of elasticity and Poisson's ratio of rocks with changes in humidity. Mining information-analytical bulletin, 7, 108-116.

6. Zhang, D., Pathegama Gamage, R., Perera, M.S.A., Zhang, C., \& Wanniarachchi, W.A. M. (2017). Influence of Water Saturation on the Mechanical Behaviour of Low-Permeability Reservoir Rocks. Energies, 10, 236. https://doi. org/10.3390/en 10020236 .

7. Cai, X., Zhou, Z., Liu, K., Du, X., \& Zang, H. (2019). Water-Weakening Effects on the Mechanical Behavior of Different Rock Types: Phenomena and Mechanisms. Applied Sciences, 9(20), 4450. https://doi.org/10.3390/app9204450.

8. Liu, X., Zhang, M., Zhang, H., Jia, Y., \& Shan, H. (2017). Physical and mechanical properties of loess discharged from the Yellow River into the Bohai Sea, China. Engineering Geology, 227, 4-11. https://doi.org/10.1016/j.enggeo.2017.04.019. 9. Shashenko, O., Shapoval, V., Kovrov, O., Skobenko, A., Tiutkin, O., Babii, K., ..., \& Slobodyanyuk, S. (2019). Determining the influence of physical nonlinearity of soil strength properties on the estimated base resistance. Eastern-European Journal of Enterprise Technologies: Applied mechanics, 6/7(102),19-27. https://doi.org/10.15587/1729-4061.2019.184946.

10. Shapoval, V., Shashenko, O., Hapieiev, S., Khalymendyk, O., \& Andrieiev, V. (2020). Stability assessment of the slopes and side-hills with account of the excess pressure in the pore liquid. Mining of Mineral Deposits, 14(1), 91-99. https:// doi.org/10.33271/mining14.01.091.

11. Sadovenko, I.O., Puhach, A. M., \& Dereviahina, N.I. (2019). Investigation of hydrogeomechanical parameters of loess massifs in conditions of technogenic underflooding and development of technical recommendations for strengthening of bases of foundations. Journal of Geology, Geography and Geoecology, 28(1), 173-179. https://doi.org/10.15421/111918. 12. Yates, K., \& Fenton, C. (2017). A methodology for examining soil-water characteristics of Banks Peninsula Loess, NZ. In: G. J.Alexander \& C. Y. Chin (Eds.) Proc. $20^{\text {th }}$ NZGS Geotechnical Symposium. Napier.

13. Sobko, B., Drebenstedt, C., \& Lozhnikov, O. (2017). Selection of environmentally safe open-pit technology for mining water-bearing deposits. Mining of Mineral Deposits, 11(3), 70-75. https://doi.org/10.15407/mining11.03.070.

14. Tereshchuk, R.M., Khoziaikina, N.V., \& Babets, D.V. (2018). Substantiation of rational roof-bolting parameters Naukovyi Visnyk Natsionalnoho Hirnychoho Universytetu, (1), 19-26. https://doi.org/10.29202/nvngu/2018-1/18.

15. Solodyankin, O., Kovrov, O., \& Ruban, N. (2015). Investigation of physical and mechanical properties of subsiding soils at the Yevpatoriyskaya ravine located in the City of Dnepropetrovsk. Naukovyi Visnyk Natsionalnoho Hirnychoho Universytetu, (1), 15-20.

16. Sdvyzhkova, O., Gapeiev, S., \& Tykhonenko, V. (2015). Stochastic model of rock mass strength in terms of random distance between joints. In: New Developments in Mining Engineering, (pp. 299-303). CRC Press. https://doi.org/10.1201/ b19901-53. 


\section{Вплив водонасичення осадових порід на їх фізико-механічні характеристики}

\author{
Д. В. Бабець ${ }^{1}$, О. С. Ковров ${ }^{1}$, С. К. Молдабаєв ${ }^{2}$, \\ Р. М. Терешук ${ }^{1}$ Д. О. Сосна
}

1 - Національний технічний університет «Дніпровська політехніка», м. Дніпро, Україна, e-mail: kovrov.o.s@ nmu.one

2 - Satbayev University, м. Алмати, Республіка Казахстан

Мета. Визначити деякі закономірності зниження міцності суглинистих грунтів і слабких осадових порід, характерних для Західного Донбасу, за умови водонасичення для оцінки їх стійкості в геотехнологіях і прогнозування георизиків.

Методика. У роботі описані дві методики експериментальних випробувань осадових гірських порід, що дозволяють визначити їх характеристики міцності за умови вологонасичення. Породні зразки пісковиків, аргілітів і алевролітів після штучного насичення шахтної водою піддавалися випробуванням на гідравлічному пресі KL 200/CЕ для визначення межі міцності на одновісне стискання. Для м'яких суглинкових порід застосовано метод визначення фізико-механічних характеристик з використанням одноплощинного зрізного приладу ПС-10 за різного вологонасичення зразків.

Результати. За результатами компресійних випробувань отримані міцнісні характеристики для зразків пісковиків, аргілітів і алевролітів, зокрема значення міцності на одновісне стискання при різних ступенях вологонасичення. Виконана статистична обробка отриманих експериментальних даних. Встановлена відносна варіація значень міцності на стискання для різних ступенів водо насичення, побудовані регресійні залежності втрати міцності осадових порід у залежності від вологості масиву. Для м'яких суглинкових порід отримані значення зчеплення $C$ і кута внутрішнього тертя $\varphi$ у залежності від вологонасичення.

Наукова новизна. Встановлено, що відносна варіація міцності на одноосьове стискання збільшується зі збільшенням вмісту води у зразках осадових порід. Найбільш інтенсивне зниження міцності зразків пісковиків, аргілітів і алевролітів відбувається при підвищенні вологості від 1 до $2 \%$. У водонасиченому стані міцність осадових порід для умов Західного Донбасу знижується в $1,5-2,5$ рази. Для м'яких суглинкових порід встановлені критичні значення міцнісних характеристик суглинкових порід у залежності від вологонасичення, за яких активуються деформаційні процеси: для світло-жовтого лесового суглинку $-C=17$ кПа і $\varphi=14^{\circ}$; для жовто-бурого щільного суглинку $-C=$ $=29 \mathrm{\kappa}$ Па і $\varphi=17^{\circ}$.

Практична значимість. Отримані поправочні коефіцієнти вологості для визначення розрахункових фізико-механічних характеристик осадових порід Західного Донбасу, що дозволяє прогнозувати геомеханічні процеси в породному масиві й визначати параметри систем розробки. Отримані значення зчеплення й кута внутрішнього тертя для суглинкових порід у залежності від вологості дозволяють прогнозувати стійкі параметри укосів кар'єрів і відвалів.

Ключові слова: Західний Донбас, осадові породи, вологонасичення, межа міцності на одновісне стискання, кут внутрішнього тертя, зчеплення порід

\section{Влияние водонасышения осадочных пород на их физико-механические характеристики}

\author{
Д. В. Бабеи ${ }^{1}$, А. С. Ковров ${ }^{1}$, С. К. Молдабаев ${ }^{2}$, \\ Р. Н. Терешук ${ }^{1}$, Д. О. Сосна ${ }^{1}$
}

1 - Национальный технический университет «Днепровская политехника», г. Днепр, Украина, e-mail: kovrov.o.s@ nmu.one

2 - Satbayev University, г. Алматы, Республика Казахстан

Цель. Определить некоторые закономерности снижения прочности суглинистых почв и слабых осадочных пород, характерных для Западного Донбасса, в условиях водонасыщения для оценки их устойчивости в геотехнологиях и прогнозирования георисков.

Методика. В работе описаны две методики экспериментальных испытаний осадочных горных пород, позволяющие определить их прочностные характеристики при условии влагонасыщения. Породные образцы песчаников, аргиллитов и алевролитов после искусственного насыщения шахтной водой подвергались испытаниям на гидравлическом прессе KL 200/CЕ для определения предела прочности на одноосевое сжатие. Для мягких суглинистых пород применен метод определения физико-механических характеристик с использованием одноплоскостного срезного прибора ПС-10 при различном влагонасыщении образцов.

Результаты. По результатам компрессионных испытаний получены прочностные характеристики для образцов песчаников, аргиллитов и алевролитов, в частности, значения прочности на одноосное сжатие при различных степенях влагонасыщения. Выполнена статистическая обработка полученных экспериментальных данных. Установлена относительная вариация значений прочности на сжатие для различных степеней водонасыщения, построены регрессионные зависимости потери прочности осадочных пород в зависимости от влажности массива. Для мягких суглинистых пород получены значения сцепления $C u$ угла внутреннего трения ф в зависимости от влагонасыщения.

Научная новизна. Установлено, что относительная вариация прочности на одноосное сжатие увеличивается с увеличением содержания воды в образцах осадочных пород. Наиболее интенсивное снижение прочности образцов песчаников, аргиллитов и алевролитов происходит при повышении влажности от 1 до $2 \%$. В водонасыщенном состоянии прочность осадочных пород для условий Западного Донбасса снижается в 1,5-2,5 раза. Для мягких суглинистых пород установлены критические значения прочностных свойств в зависимости от влагонасыщения, при которых активируются деформационные процессы: для светложелтого лессового суглинка $-C=17$ кПа и $\varphi=14^{\circ}$; для желто-бурого плотного суглинка $-C=29$ кПа и $\varphi=17^{\circ}$.

Практическая значимость. Получены поправочные коэффициенты влажности для определения расчетных физико-механических характеристик осадочных пород Западного Донбасса, что позволяет прогнозировать геомеханические процессы в породном массиве и определять параметры систем разработки. Полученные значения сцепления и угла внутреннего трения для суглинистых пород в зависимости от влажности позволяют прогнозировать устойчивые параметры откосов карьеров и отвалов.

Ключевые слова: Западный Донбасс, осадочные породы, влагонасыщение, предел прочности на одноосное сжатие, угол внутреннего трения, сцепление пород

Recommended for publication by O.O. Sdvyzhkova, Doctor of Technical Sciences. The manuscript was submitted 07.12.19. 